\title{
POLACY W SŁOWACKIEJ PUBLICYSTYCE I POLITYCE OD LAT 30. DO 60. XIX WIEKU
}

\section{Dušan Škvarna}

http://orcid.org/0000-0001-5636-4557

Uniwersytet Mateja Bela w Bańskiej Bystrzycy (Słowacja)

\section{ABSTRACT \\ POLES IN SLOVAK JOURNALISM AND POLITICS FROM THE 1830S TO THE 1860S}

This paper sheds light on the perception of the Polish people, Polish politics, and their issues in Slovak journalism between 1830 and 1872 . On the whole, the views were limited by the social opinions voiced by Slovak nationalists as well as by their interests and the general weakness of their National Movement. Slovak nationalists refused to accept political concepts that, on the one hand, supported the creation of nation states (by "large" nations such as Poland), and on the other hand, called for the assimilation of "small" nations living within them. This would spell the end of the Slavs and Romanians settled in Hungary, as Hungary would reform into one single national Hungarian state. Among all Austro-Slavs, the fear of "Magyarisation" contributed to the most intense and widespread Slavic solidarity and Russophilia in the Slovak-speaking environment. It also determined the difficult approach to the Polish issues. The Slovak nationalists sympathised with the Polish fate, however, at the same time, they had difficulties with accepting the Poland-Russia conflict. That is why we can find quite varied opinions of Poles and Polish issues. Idealising the Poles, Polonophilia, sympathising with Poles as regards their problems, careful and neutral views of those problems, efforts to limit the Poland-Russia conflict, and critical views of Poles were all entwined. For example, pro-Polish sympathies dominated in the Slovak National Movement in the 1830s, whereas in the 1840s the sympathies shifted towards Russia, despite the fact that some nationalists supported the Poles and their Uprising in Halych. The real Slovak-Polish co-operation can be seen particularly during the revolution in 1848-1849. Out of the Slovak political ideology emerged the Pan-Slavic work Slovanstvo a svet budúcnosti [Slavdom and the world of the future] by L'. Štúr, which combined the Slav perspective with the connections to Russia. The Polish issues were mainly present in the 1860s. During that time, the more conservative political wing, "Stará škola" [The Old School], was looking for support in the imperial Vienna, showing strong Russophilism and critical attitude to the Polish uprising. In contrast, the more liberal political line, "Nová škola" [The New School], striving for co-operation with Hungarian political parties, showed understanding for the Polish aversion and was critical of the imperial Russia. After the Austro-Hungarian Compromise, 
the Slovak politics and culture considerably weakened. The interest in glossing over the problems of the northern neighbour also declined. The Polish issues re-entered Slovak journalism again after the 1890 s in connection with analysing new geo-political affairs on the continent and polarisation of the European superpowers.

Keywords: Slavic solidarity, Slovak-Polish contacts and Hungarian politics, Russophilism, Polonophilism, Polish Uprising of 1863 and Slovak politics.

Słowa kluczowe: wzajemność słowiańska, kontakty polsko-słowackie a polityka węgierska, rusofilstwo, polonofilstwo, powstanie styczniowe a polityka słowacka.

Celem artykułu jest ukazanie, jak zmieniał się wizerunek Polaków, polityki polskiej oraz historii w słowackiej kulturze, publicystyce i polityce od lat 30. do 60. XIX wieku. Przedstawiony obraz dotyczy nie tyle polskich realiów, ile przede wszystkim zainteresowań, możliwości i ograniczeń kultury słowackiej, jej instytucji i reprezentującej je postaci. Jego geneza sięga początków XIX wieku, kiedy zaczął się tworzyć nowoczesny nacjonalizm. W każdym środowisku narodowym wzrastało zainteresowanie poznaniem nie tylko samego siebie, ale też życia, historii oraz kultury innych, zwłaszcza sąsiadujących i bliskich sobie narodów. Tworzenie wielobarwnej palety autostereotypów i heterostereotypów, której autorami byli pełni entuzjazmu romantycy, stanowiło bardzo ważny element kształtowania tożsamości poszczególnych narodów. Prawdą jest, że autostereotypy i heterostereotypy bliskich, „braterskich” narodów wypełnione były przyjazną, pozytywną i najczęściej idealizującą treścią, w obrazach zaś „wrogów”, nieprzyjaciół, dominowały treści negatywne.

W omawianym okresie tradycyjne poczucie słowiańskiej bliskości w Europie Środkowo-Wschodniej i na Bałkanach z zaskakującą szybkością zaczęło przekształcać się w solidarność, pomoc, a w końcu w ideologię, nazywaną najczęściej wzajemnością słowiańską. Stała się ona jedną z kluczowych idei głoszonych wśród słowiańskich narodów głównie przez ich elity kulturalne i polityczne. Ideologia ta pomagała im wzmacniać poczucie własnej wartości, a w działaniach politycznych małych narodów słowiańskich, zwłaszcza takich jak Słowacy, odegrała również rolę ważnego narzędzia w walce obronnej przed dyskryminacją ze strony silniejszych narodów. Nie można jednak nie zauważyć, że mimo ograniczeń wynikających z braku podmiotowości politycznej wzajemność słowiańska posiadała zróżnicowaną treść, przybierała pewną formę, cechowała się intensywnością i spełniała określone funkcje. Pojawiło się wiele koncepcji wzajemności słowiańskiej, przy czym niektóre z nich mogły się jawić jako zaprzeczenie słowiańskiej solidarności. W latach 60 . XIX wieku pokazał to na przykładzie Polaków słowacki polonofil Ján Palárik: „Tylko polskie plemię, jedynie z pewnymi wyjątkami, pozostało jak dotąd nieprzesiąknięte tą nową koncepcją wzajemności słowiańskiej, tak więc przeciwstawiało się ogólnosłowiańskim wysiłkom, łącząc się często także z wrogami i ciemiężcami innych słowiańskich plemion"1.

1 J. Palárik, Za reč a práva l'udu. Kultúrnopolitické články, Bratislava 1956, s. 180. 
Różnorodność koncepcji wzajemności słowiańskiej sprawiła, że w różnych uwarunkowaniach geopolitycznych poszczególne narody słowiańskie określiły własne, specyficzne interesy wynikające z idei wzajemności. Fenomenem, który wywarł dominujący wpływ na treść wzajemności słowiańskiej, była postawa wobec Rosji i w konsekwencji wobec konfliktu polsko-rosyjskiego. Wpłynęło to dość znacząco również na słowacki ruch narodowy. Wzajemność słowiańska i rusofilstwo odegrały wśród Słowaków tak silną rolę, jak w żadnym innym środkowoeuropejskim słowiańskim ruchu narodowym. Słowacka emancypacja była zatem ściśle związana z zainteresowaniem innymi Słowianami i z szukaniem z ich strony pomocy. W tym kontekście zrozumiałe się wydaje, dlaczego Słowacy źle znosili „bratobójczą” walkę dwóch słowiańskich narodów. Przeważnie starali się pogodzić rusofilstwo i polonofilstwo, akcentując przy tym przede wszystkim interes Słowiańszczyzny i niechętnie opowiadając się po jednej czy drugiej stronie konfliktu. Przypominało to trochę wiarę Polaków w możliwość pogodzenia Słowaków, Chorwatów i Serbów z Madziarami. Polacy życzyli węgierskim Słowianom, aby uzyskali swobody narodowe, szukali sojuszników, ale jednocześnie nie wchodzili w konflikt z Madziarami, a wręcz odwrotnie. Polaków i Madziarów łączył wspólny interes geopolityczny: opór wobec mocarstw będących twórcami i gwarantami ładu wiedeńskiego, zwłaszcza zaś Petersburga i Wiednia, które stały na przeszkodzie polskiego i węgierskiego rozwoju i wolności. Podobną „schizofreniczną” postawę można zaobserwować w słowackiej polityce i kulturze wobec Polaków i Rosji w całym XIX wieku. W słowackim środowisku narodowym oba przeciwstawne bieguny (rusofilski i polonofilski) zazębiały się w różny sposób w zależności od różnorakich okoliczności. Ogólnie jednak przeważała przychylność w stosunku do Rosjan.

Z faktu, że Słowacy w XIX wieku nie byli niepodległym narodem, wypływała polityczna słabość słowackiego ruchu narodowego. Z wyjątkiem kilku krótkich okresów ruch ten dodatkowo osłabiała polityka węgierska i dążenia asymilacyjne Madziarów. W zasadzie przez całe stulecie, aż do 1918 roku, słowaccy politycy nie uzyskali silniejszej pozycji na węgierskiej scenie politycznej. Tym bardziej uporczywie szukano wsparcia u innych narodów słowiańskich i chętniej zwracano się ku rusofilstwu. Jest to logiczne, ponieważ Słowacy, w przeciwieństwie do Polaków, nie mieli żadnych negatywnych doświadczeń w relacjach z Rosją. Do lat 30. XIX wieku nie mieli z nią nawet bezpośrednich kontaktów. Tym bardziej postrzegali Rosję jako jedyne niezależne państwo słowiańskie, podziwiali jej coraz silniejszą pozycję polityczną na arenie międzynarodowej i idealizowali jej „słowiańskiego ducha”. Wielu słowackich działaczy narodowych widziało w Rosji obrońcę, a część z nich także potencjalnego wyzwoliciela nie tylko Słowaków, ale ogólnie wszystkich Słowian².

Kontakty między Słowakami a innymi narodami słowiańskimi były utrudnione z powodu bardzo słabego zaplecza instytucjonalnego i możliwości finansowych słowackiego ruchu narodowego, który liczył niewielu członków. Z nielicznymi wyjątkami ruch ten był zmuszony działać jedynie na polu kultury, co nie wymagało

2 L. Haraksim, Slovanská idea v brozenské ideologii Slováků [w:] Slovanství v národním životě Čechů a Slováki̊, red. V. Št astný et al., Praha 1968, s. 139. 
znacznych nakładów finansowych i ram organizacyjnych. Mowa tu przede wszystkim o dziennikarstwie i twórczości literackiej. Osobiste kontakty między słowackimi działaczami narodowymi a innymi Słowianami były rzadkie, a słowaccy politycy nie byli tak silni, by odgrywać znaczącą rolę w polityce międzynarodowej. Za pośrednictwem jednak słowa drukowanego i korespondencji słowaccy działacze narodowi i społeczeństwo poznawali świat słowiański, stosunki międzynarodowe i meandry polityki, w końcu pisali własne scenariusze polityki zagranicznej.

Sytuacja taka znajduje również odzwierciedlenie w kontaktach słowacko-polskich, które możemy śledzić, począwszy od lat 20. XIX wieku. W słowackich dziełach literackich pojawiają się polskie motywy historyczne lub literackie, ale mowa tu jedynie o krótkich formach (artykułach, wierszach, recenzjach). Niekiedy wątki polskie występują w kontekście opisu jakichś szerszych europejskich, ewentualnie słowiańskich zjawisk. W słowackiej kulturze dominowało pozytywne nastawienie do Polaków, Polski, polskiego języka, kultury i historii, pojawiały się w niej również polskie wpływy i inspiracje. Można to zaobserwować przede wszystkim u głównych przedstawicieli preromantycznej generacji: Pavla Jozefa Šafárika, Jána Kollára i Jána Hollý' goo $^{3}$. Z drugiej strony głęboko zakorzeniło się u tych pisarzy rusofilstwo, $\mathrm{z}$ tego więc powodu krytykowali oni powstanie listopadowe 1830 roku jako działanie antysłowiańskie.

$* * *$

W latach 30. XIX wieku słowackie odrodzenie narodowe nabierało treści politycznych. Na jego czele stanęli przedstawiciele młodego pokolenia, zwanego szturowcami lub młodosłowakami. Charakteryzowało ich pragnienie wolności, które wcześniej można było zaobserwować w Europie Zachodniej, ale również słowiański entuzjazm i sympatie propolskie. Młodosłowacy postrzegali powstanie listopadowe z 1830 roku jako walkę o wolność Polaków i Słowian, kilku z nich brało nawet udział w działaniach zbrojnych, na przykład poeta Samo Chalupka. Interesowali się też historią Polski, podziwiali polską literaturę romantyczną, a szczególnie twórczość Adama Mickiewicza i Juliusza Słowackiego. Nawiasem mówiąc, fenomen literatury polskiej, zwłaszcza romantycznej, pozostał aż do I wojny światowej głównym tematem słowackiej polonistyki.

W połowie lat 30. XIX wieku słowaccy działacze narodowi, za pośrednictwem Morawianina Františka Cyrila Kampelíka, nawiązali kontakty z polskimi radykałami członkami tajnych stowarzyszeń studenckich działających w Galicji i w Wiedniu, którzy mieli powiązania z polskimi ośrodkami demokratycznymi na emigracji we Francji ${ }^{4}$. Kontakty te osłabły dopiero po 1841 roku, kiedy w monarchii habsburskiej wszczęto rozległe śledztwo w sprawie tajnych stowarzyszeń i kontaktów między studentami słowiańskimi. W latach 40 . orientacja polonofilska, a zarazem radykalizm

3 J. Hvišč, Slovensko-pol’ské literárne vzt'ahy (1815-1918), Bratislava 1991, s. 17-21.

4 L. Haraksim, Od Kollárova slovanství k slovenství (1835-1848) [w:] Slovanství v národním životě Čechů a Slováků, s. 159; V. Žáček, Z revolučných a politických pol'sko-slovenských stykov v dobe predmarcovej, Bratislava 1966, s. 32-106. 
słowackiego ruchu narodowego, osłabły, a w związku z tym zmniejszyło się także zainteresowanie problemami polskimi. Ludovít Štúr i jego otoczenie postanowili unowocześnić słowackie społeczeństwo i działać na rzecz emancypacji Słowaków metodą „małych kroków”. Dali pierwszeństwo legalnym formom działalności, deklarowali lojalność wobec Węgier jako ojczyzny Słowaków. Chociaż atrakcyjność i doniosłość idei wzajemności słowiańskiej nie zmieniła się dla nich, starali się jednak pomniejszyć wpływ kształtowanego przez los konfliktu rosyjsko-polskiego, zmieniali więc jej treść. Dominującym i definiującym elementem wzajemności słowiańskiej było z jednej strony, podobnie jak w przypadku Jána Kollára ${ }^{5}$, rusofilstwo, z drugiej strony natomiast zaczęły pojawiać się także oznaki madziaroslawizmu i austroslawizmu, które w pełni rozwinęły się po marcu 1848 roku.

W latach 40. XIX wieku Słowacy znaleźli się w sferze dyplomatycznych działań polskiej emigracji - ks. Adama Jerzego Czartoryskiego, którego agenci wykazywali dużą aktywność w szerzeniu propolskiej propagandy. Emigracyjni emisariusze starali się zwalczać rusofilstwo i wpływać na myślenie węgierskich Słowian, by zwrócili się przeciw Rosji. Kontynuowali więc misję, którą już wcześniej rozpoczęli wśród Słowian na Bałkanach ${ }^{6}$. Nie udało im się jednak wpłynąć znacząco na myślenie słowackich działaczy narodowych. Przedstawiciele głównego nurtu ruchu narodowego, skupieni wokół Ludovíta Štúra - a najbardziej on sam - pragnęli uniknąć podejrzeń (tajna policja, węgierscy politycy) o słowiański i polityczny radykalizm (panslawizm, kontakty z radykalną opozycją na Zachodzie). Chociaż Štúr nie odrzucał kontaktu z polskimi emigrantami, w tym z emisariuszami Czartoryskiego, odmówił jednak współpracy z nimi i nie nawiązał silniejszych kontaktów.

Największy zakres miała i największe poruszenie wywołała misja Antoniego Rietha, byłego cesarskiego żołnierza, który w 1843 roku wyemigrował z Prus do Paryża ${ }^{7}$. Brał tam udział w przygotowaniach powstania w Galicji, które miało być sygnałem do ogólnopolskich wystąpień niepodległościowych. W tym celu z upoważnienia księcia Czartoryskiego Rieth przybył na Węgry, gdzie starał się, przede wszystkim w środowisku skupionym wokół Kollára i Štúra, zdobyć poparcie nie tylko dla rozwiązania kwestii polskiej, ale także dla przygotowywanego powstania w Galicji. Rieth nie wykonał jednak tego zadania skutecznie, ponieważ zachowywał się nieprzekonująco i działał niewiarygodnie, co sprawiło, że Štúr upewnił się w przekonaniu o konieczności odrzucenia jego propozycji współpracy. Roztropność Štúra okazała się uzasadniona, ponieważ ostatecznie Rieth zdradził swoją misję, wstępując do tajnych służb austriackich jako agent ${ }^{8}$.

Słowaccy działacze narodowi obawiali się koncepcji Hotelu Lambert nie dlatego, że nie życzyli Polakom wolności, ale dlatego, że przywrócenie polskiego państwa

5 L. Haraksim, Od Kollárova slovanství k slovenství (1835-1848), s. 163.

6 Z. Bik, ,Do Stowaków, którzy jeden dom wraz z Galicjanami zamieszkują”. Dzieje tajnej misji księcia Adama Czartoryskiego na Stowacji [w:] Węry-Polska w Europie Środkowej. Księga pamiatkowa ku czci Profesora Wactawa Felczaka, red. A. Cetnarowicz, C.G. Kiss, I. Kovács, Kraków 1997, s. 129.

7 O misji Rietha zob.: V. Žáček, op. cit., s. 120-146.

8 Z. Bik, op. cit., s. 135. 
mogło nastąpić jedynie poprzez wywołanie wielkiego, ogólnoeuropejskiego kryzysu politycznego. To właśnie niesłowiańscy politycy i myśliciele (niemieccy i madziarscy radykałowie), którzy popierali rozwiązanie polskiej kwestii przez odnowienie polskiego państwa, głosili dwie niemożliwe do przyjęcia dla austriackich Słowian koncepcje. Po pierwsze, za konieczny warunek postępu uważali upadek „wschodnich” monarchii, co jednak doprowadziłoby do destabilizacji Europy Środkowej i mogłoby stwarzać groźbę wyginięcia Słowian. Po drugie, wielu z nich bezpośrednio głosiło konieczność zaniku małych, przede wszystkim słowiańskich grup etnicznych ${ }^{9}$. Dla Słowaków stanowiło to tym bardziej poważne zagrożenie, gdyż taka koncepcja przyszłej Europy Środkowej była zasadniczo zgodna z madziaryzacyjnym kierunkiem władz węgierskich. Nie tylko Štúr, ale wszyscy przywódcy austriackich Słowian zdawali sobie sprawę, że tak radykalna transformacja Europy Środkowej, w odniesieniu do sytuacji na Węgrzech i własnej słabości, byłaby dla nich destrukcyjna.

W latach 40. XIX wieku w słowacki ruch narodowy angażowali się też działacze, którzy odchodzili od rusofilstwa. Chociaż należeli do frakcji szturowskiej, wyrażali bardziej radykalne poglądy, pozytywnie postrzegali politykę reform węgierskiej szlachecko-liberalnej opozycji i otwarcie wyrażali sympatie dla polskiej walki o wolność. Znajdujemy ich głównie w Budzie i Peszcie (np. Štefan Marko Daxner, Alexander Vrchovský) i we wschodnio-słowackich miastach. Przede wszystkim utrzymywali oni kontakty z Polakami mieszkającymi na Węgrzech, a za ich pośrednictwem z Towarzystwem Demokratycznym Polskim we Francji. Najbardziej intensywnie przejawiało się to w latach 1846-1847, kiedy byli pod wrażeniem wydarzeń w Krakowie i Galicji.

Na przykład Ján Francisci-Rimavský, który w tym czasie studiował prawo w ewangelickim liceum w Lewoczy i w Preszowie, entuzjastycznie przyjął powstanie krakowskie. Postrzegał je jako początek walki o wolność wszystkich Słowian i przyznał mu wyjątkowe znaczenie historyczne. W jednym z listów do Samo Bohdana Hroboňa z kwietnia 1846 roku wyraził to następująco: ,[...] wydarzenie to jest wielce pamiętne dla Słowian, ponieważ jest pierwszym ruchem ich życia, polskie powstanie jest pierwszym aktem, w którym Słowianie wystąpili odważnie z mieczem w ręku przed światem, aby wywalczyć uznanie swojej narodowości [...]. To [...] jest początek pamiętnej walki na śmierć i życie Słowiańszczyzny z obcymi, walki o władzę nad światem" ${ }^{\prime 10}$. Zdradził w nim też, że publicznie mówi się, że pod tym naporem „Austria się ponoć rozsypie”" nącego radykalnych zmian, ale dokument ten pokazuje również charakterystyczny dla tamtych czasów zapał części słowackich elit narodowych na rzecz radykalnych zmian społecznych i silnej wspólnoty słowiańskiej, a także wiarę w siłę Polaków.

Francisci spotykał się w Preszowie z polskim agentem Karolem Zielonką, który działał także wśród uczniów preszowskiego liceum. Pod wpływem Zielonki na przełomie lat 1846 i 1847 napisał broszurę Zrkadlo pre slovenský l’ud [Zwierciadło dla

9 D. Škvarna, Obraz Ruska u neslovanských a slovanských národov habsburskej monarchie [w:] Východná dilema strednej Európy, a kol. T. Ivantyšynová, D. Kodajová, Bratislava 2010, s. 19-30.

10 Listy Jána Francisciho 1, pripr. M. Eliáš, Martin 1990, s. 135.

11 Ibidem, s. 132. 
słowackiego ludu], w której wzywał Słowaków, aby powstali i obalili swoich „ciemiężców", oraz apelował o wyzwolenie Polaków. Rękopis tego dzieła Francisciego, zanim ukazał się drukiem, wpadł w ręce prezydenta policji austriackiej Josefa Sedlnickego, a następnie zaginą $1^{12}$. A Karol Zielonka w rzeczywistości okazał się agentem austriackiej policji.

$$
* * *
$$

Nowe możliwości rozwoju stosunków słowacko-polskich pojawiły się w okresie wydarzeń rewolucyjnych w marcu 1848 roku. Również idea wzajemności słowiańskiej nabrała wtedy nowego, politycznego znaczenia. Wszystkie ruchy narodowe wśród Słowian domagały się wówczas uznania praw narodowych, jednocześnie wykazywały silną solidarność z innymi narodami słowiańskimi i wzywały do politycznej współpracy Słowian. Po raz pierwszy znalazło to odzwierciedlenie na przełomie marca i kwietnia 1848 roku podczas negocjacji Słowian austriackich w Wiedniu, a następnie w czerwcu na Kongresie Słowiańskim w Pradze. Tymczasem słowaccy narodowcy, w swoim najważniejszym dokumencie zatytułowanym ,Žiadosti slovenského národa" [Żądania narodu słowackiego], który przyjęli 10 lipca w Liptowskim Mikulaszu, a który chcieli wysłać węgierskiemu parlamentowi i królowi, umieścili również punkt dotyczący „braterskiego narodu polskiego” w Galicji. Domagali się, aby zapewniono mu „wolność, którą się cieszymy” i wzywali, „aby wszystkie narody, które są pod władzą węgierską, swoimi oficjalnymi sposobami [...] u Jego Wysokości naszego króla i pana w Wiedniu o to błagalnie nalegali, aby w końcu nieszczęśliwy naród sprawiedliwość i ułaskawienie zyskał"13. Ten punkt można rozumieć w taki sposób, że słowacki ruch narodowy starał się pozytywnie nastawić do siebie Polaków i pozyskać ich do przyszłej współpracy, zwłaszcza w przypadku rywalizacji z Madziarami.

Silniejsze więzi nawiązali przedstawiciele Słowaków z Polakami przede wszystkim na Kongresie Słowiańskim. Štúr wraz z Karolem Libeltem i Jerzym Lubomirskim należeli do grupy delegatów, która zaproponowała wówczas bardziej radykalną politykę słowiańską ${ }^{14}$. Zanim jednak ta grupa zdołała sformułować jaśniejszy program i rozwinąć swoją strategię, na zjeździe została przeforsowana koncepcja austroslawistyczna (austrofederalna).

Dwa miesiące później, w sierpniu 1848 roku, Štúr przedstawił swoją słowiańską i europejską wizję w chorwackiej gazecie „Slavenski jug”. W tym czasie przebywał w Zagrzebiu, gdzie jego zwolennicy z pomocą Chorwatów i Serbów przygotowywali powstanie zbrojne (tzw. powstanie wrześniowe). W serii artykułów ze słowiańskiego punktu widzenia analizował wydarzenia, które miały miejsce w Europie do początku 1848 r. Wysoko ocenił rewolucję francuską z 1789 roku, przy czym szczególnie mocno podkreślał znaczenie przemian politycznych po uchwaleniu konstytucji w 1791

12 V. Žáček, op. cit., s. 182-184.

13 Dokumenty slovenskej národnej identity a štátnosti I, Bratislava 1998, s. 310.

14 J.V. Frič, Paméti, Praha 1960, s. 101, 102. 
roku, oraz rewolucji w Paryżu z lutego 1848 roku. Nazwał je drzwiami otwierającymi rewolucyjną falę w całej Europie. Štúr był także przekonany, że rozwój wydarzeń na kontynencie zależy przede wszystkim od sytuacji we Francji, toteż konstatował, że: „[...] z egzystencją Republiki Francuskiej jest związany również wolny rozwój wszystkich pozostałych państw. Ten jest jej konsekwencją i jeśli republika zbankrutuje, natychmiast kraj, którego rozwój jest cierniem w oku, zmobilizuje wszystkie swoje siły, aby zaprząc narody do starego jarzma”. Przesadnie optymistycznie nastawiony Štúr uważał jednak takie rzeczy za niemożliwe ${ }^{15}$.

Štúr przybliżył również rozwój polityczny większości krajów europejskich, które ogarnęła rewolucja. W związku z kwestią niemiecką stwierdził, że nie można mieć nic przeciwko wysiłkom Niemców dążących do utworzenia własnego państwa, ale Słowianie nie zgadzają się, aby Niemcy przejęli słowiańskie ziemie: „Czechy i Morawy, połowę Poznańskiego, Śląsk, Krainę, Istrię, Karyntię i Styrię" "16. Wypominał Niemcom brak poszanowania praw i lekceważenie dążeń wolnościowych Słowian, a jako przykład podawał doświadczenia polskie. Otóż według Štúra niemieckie elity, mimo obietnic, ignorowały prawa Polaków w Poznańskiem i Galicji oraz krzewiły tam swoje wizje władzy. Szczególnie ostro potępił niemiecką politykę wobec Polaków w Poznańskiem od wiosny 1848 roku. Z tekstu Štúra emanuje empatia i życzliwość wobec Polaków. Jednocześnie jednak nie przekroczył granicy swojego rusofilstwa. W zasadzie milczał o ucisku Polaków w zaborze rosyjskim, wyraził jedynie nadzieję, że wielka przyszłość czeka Rosję, „kiedy duch słowiański w Rosji jeszcze bardziej się rozpowszechni, kiedy także tam pojawi się postęp wolności, ziemia ta wykona wielkie i ważne dzieła dla Słowiańszczyzny, ważne i rozstrzygające dla świata” ${ }^{17}$. Štúr prawdopodobnie dość naiwnie wierzył, że „nowa” Rosja okaże Polakom zrozumienie w sprawie dążeń do uzyskania swobód narodowych.

Przejawem słowiańskiego braterstwa deklarowanego na Kongresie Słowiańskim w Pradze i zbliżenia postaw austriackich Słowian był udział grupy polskich ochotników w powstaniu słowackim we wrześniu 1848 roku. Było to pierwsze zbrojne wystąpienie Słowaków w obronie swoich praw przeciw władzom węgierskim. Oprócz Słowaków, setek Czechów, kilkudziesięciu Chorwatów i Serbów walczyła w nim także grupa Polaków pod dowództwem kapitana Karola Bońkowskiego. Powstanie to trwało zaledwie dwa tygodnie, a po jego niepomyślnym zakończeniu polscy bojownicy, którzy wyróżnili się w kilku zbrojnych akcjach, udali się wraz z innymi Polakami na Węgry, by walczyć o ich niepodległość, a tym samym także o wolność Polaków ${ }^{18}$. Przy rozstaniu ze Słowakami mieli powiedzieć, że „wdzięcznie przelewali swoją krew za bratni słowacki naród, ale [Polacy - D.Š.] rządowi austriackiemu nie wierzą" 19 .

\footnotetext{
15 Dokumenty k slovenskému národnému hnutiu I, zest. F. Bokes, Bratislava 1962, s. 31-32.

16 Ibidem, s. 34.

17 Ibidem, s. 39.

18 Zob. D. Rapant, Slovenské povstanie roku 1848-49, diel 5, čast' 2: Mená a veci, Bratislava 1972,

19 J.M. Hurban, Ludovit Štúr - Rozpomienky, Bratislava 1959, s. 666.
} s. 32 . 
Wiadomo, że polscy politycy i legioniści - także podczas rewolucji 1848-1849 starający się złagodzić konflikt między przywódcami węgierskimi a Słowianami i Rumunami - opowiadali się za prawami obywateli Węgier innej niż madziarska narodowości, a nawet przyczynili się do zmiany węgierskiej polityki narodowej w kierunku uznania praw mniejszości narodowych. Ponieważ Polacy skupiali się głównie na wschodzie i południu Węgier, nawiązując tam osobiste kontakty z politykami rumuńskimi, chorwackimi i serbskimi, to nie wiadomo, czy którykolwiek z nich prowadził poważniejsze rozmowy ze słowackimi działaczami narodowymi. Ponadto dzieliły ich odmienne programy. Podczas gdy Polacy, także w ciągu 1849 roku, widzieli upadek monarchii Habsburgów jako jeden z warunków przywrócenia polskiej państwowości, słowaccy narodowcy łączyli wolność Słowaków z federalizacją monarchii i uznaniem Słowacji za kraj koronny. Zatem wyobrażenia o rozwiązaniu kwestii słowackiej i polskiej nie tylko się nie przenikały, ale wzajemnie się wówczas wykluczały.

W okresie neoabsolutyzmu w latach 50. XIX wieku nastąpiło ograniczenie wolności prasy i publikacji, osłabły również kontakty słowacko-polskie. Na początku tej dekady ukazało się utopijne dzieło Slovanstvo a svet budúcnosti [Słowiańszczyzna i świat przyszłości], w którym pojawiła się wizja przyszłości Słowian. Jego autor, Ludovít Štúr, głęboko rozczarowany wynikami rewolucji 1848-1849 i polityką Habsburgów, zdecydowanie zmienił swoją koncepcję polityczną. Pokłosie rewolucji oceniał negatywnie. Twierdził, że tożsamość i zarazem cała cywilizacja Słowian są zagrożone przez upadający Zachód, a zwłaszcza żądnych władzy Niemców, Madziarów i Włochów. Wykluczył możliwość, by monarchia austriacka - u progu swojego upadku - mogła jeszcze stać się państwem federalnym. Odrzucił również połączenie zachodnich i południowych Słowian w jedną federację, którą uznał za niezdolną do egzystencji. Silne rusofilstwo Štúra przerodziło się w otwarty panslawizm. Ocalenie i wolność Słowian widział jedynie w ich zjednoczeniu z carską Rosją. Chociaż Štúr idealizował Rosję, dostrzegał także niektóre jej negatywne cechy, a przywództwo jej w słowiańskim świecie uzależniał od przeprowadzenia reform. Swojej wizji nie ograniczał czasowo, a jego ostatnie dzieło jest bardziej polityczną refleksją niż programem politycznym.

Równocześnie w tej publikacji Štúr krytycznie wypowiedział się o Polakach. Według niego nie poradzili sobie oni ze swoją historyczną rolą i nawet współcześnie nie mają siły i zdolności do przewodzenia Słowianom. „Niekończące się” spory rosyjsko-polskie są według Štúra „w istocie walką o hegemonię wśród Słowian”, którą przegrał słabszy ${ }^{20}$. Dzieło to, które zostało napisane przez autora w języku niemieckim i opublikowane po raz pierwszy w Moskwie w 1867 roku, nie miało większego wpływu na ogół Słowaków, ale w okresie dualizmu pomogło wzmocnić nurt rusofilski pośród bardziej konserwatywnej części słowackiej elity politycznej.

20 L. Štúr, Slovanstvo a svet budúcnosti, Bratislava 1993, s. 155. 
Słowaccy politycy i publicyści najintensywniej interesowali się sprawami polskimi w latach 60. XIX wieku przede wszystkim z powodu wybuchu powstania styczniowego w 1863 roku, które było tłumione przez wojska rosyjskie prawie półtora roku. W tym powstaniu nie szło o konflikt polsko-niemiecki, w którym po stronie Polaków staliby wszyscy wykształceni Słowianie, ale polsko-rosyjski, a więc był to spór wewnątrzsłowiański. To wydarzenie podzieliło także słowackich polityków, którzy po dyplomie październikowym 1860 roku zaczęli się na nowo organizować i definiować swój program polityczny. Wpłynęło to również na zajęcie stanowiska wobec polskiego powstania. Stanowisko to było znów determinowane przez rozkład sił politycznych i interesów w monarchii habsburskiej oraz na kontynencie europejskim.

Austria przyjęła wybuch powstania z uczuciem Schadenfreude, odpowiadało jej osłabienie Rosji, z którą stosunki od 1853 roku tylko się pogarszały. Wiedeń jednak obawiał się, aby to powstanie nie wywołało innych buntów, nie tylko w Galicji, ale także na Węgrzech, w krajach koronnych monarchii zamieszkanych przez Niemców, Włochów czy Słowian południowych. Groźba destabilizacji stosunków krajowych i europejskich spowodowała, że Wiedeń zareagował na powstanie powściągliwie i zajął stanowisko neutralne; nie opowiedział się ani po stronie powstańców, ani po stronie caratu.

Niesłowiańscy, przede wszystkim liberalni i lewicowi, politycy i intelektualiści od dawna uważali Rosję za główne zagrożenie wolności, a walkę Polaków o niepodległość za jeden z symboli europejskiej wolności. Z najnowszym polskim powstaniem sympatyzowały nie tylko zachodnioeuropejskie mocarstwa, ale także politycy opowiadający się za zjednoczeniem Włoch, Niemiec, a także węgierska opozycja państwowa w kraju i węgierscy politycy na emigracji. Węgierskie władze miały nadzieję, że powstanie Polaków może zdestabilizować sytuację również w monarchii habsburskiej oraz pomóc wzmocnić niezależność Węgier od Wiednia, a nawet umożliwić ich całkowitą niepodległość państwową. Nic dziwnego, że powstanie znalazło pozytywny odzew na Słowacji, przede wszystkim wśród węgierskiej szlachty, bogatszych mieszczan i inteligencji ${ }^{21}$.

Znajdująca się w głównym nurcie słowackiej polityki tak zwana Stara Szkoła ostro sprzeciwiała się tej węgierskiej koncepcji politycznej i zajęła krytyczne stanowisko wobec polskiego powstania. Stara Szkoła widziała gwarancję rozwoju Słowaków w zachowaniu i stabilności monarchii, w sojuszu z polityką habsburską, we wzajemności słowiańskiej i rusofilstwie. Początkowo wprawdzie bliska konserwatywnej Starej Szkole prasa słowacka informowała powściągliwie o powstaniu styczniowym i konsekwencjach, jakie ono spowodowało ${ }^{22}$, określając je „niefortunnym zdarzeniem”, stopniowo jednak nasilała się krytyka Polaków i wzrastała przychylność

21 A. Divéky, Wegrzy a Polacy w XIX stuleciu, Warszawa-Lublin-Łódź-Kraków 1918, s. 115, 116.

22 Zob. np. Pol'ská otázka, „Pešt'budínske vedomosti”, 24 III 1863, nr 24, s. 1-2; Zprávy zahraničné. Rusko, „Pešt'budínske vedomosti”, 3 IV 1863, nr 27, s. 3. 
wobec Rosji i cara-reformatora ${ }^{23}$. Polaków krytykowano za wyobcowanie się ze Słowiańszczyzny, za rozbijanie słowiańskiej jedności. Protestowano przeciwko poczynaniom, które osłabiały wspólnotę i spójność Słowian, a za takie uważano powstanie, które skierowane było przeciwko jedynemu słowiańskiemu państwu ${ }^{24}$. Reprezentanci Starej Szkoły postrzegali powstanie jako narzędzie polityki Niemców i Madziarów; działanie, które zagraża integralności monarchii habsburskiej i pozycji austriackich Słowian. Kwestionowali narodowy charakter powstania, ponieważ miało ono realizować przede wszystkim cele szlachty. Skrytykowali również orientację powstańców na Anglię i Francję, które były wrogie wobec Rosji i dążyły do jej osłabienia, a następnie zniszczenia. Przedstawicielom słowackiej Starej Szkoły nie podobało się także to, że słowiański problem był według nich postrzegany przez powstańców przez pryzmat opinii francuskich i niemieckich ${ }^{25}$. Potępiali także niesprawiedliwą ich zdaniem politykę powstańców wobec narodów kresowych oraz próby rozszerzenia powstania w głąb terytorium Rosji. Skrytykowali powstańców za przemoc, konfiskowanie majątków, zmuszanie młodych ludzi do wstępowania w szeregi powstańcze ${ }^{26}$. Według reprezentantów Starej Szkoły powstanie tylko pogarszało sytuację Polaków, a rozwiązanie kwestii polskiej było możliwe jedynie na drodze konstytucyjnej i poprzez wspieranie reform caratu ${ }^{27}$.

W nieoficjalnych kontaktach reprezentantów Starej Szkoły można jednak dostrzec też bardziej przychylne podejście do kwestii polskiej. W połowie lat 60. XIX wieku powstało wiele dokumentów, które miały na celu doprecyzowanie kierunku słowackiej polityki. Jednym z nich był Program Slovenska [Program Słowacji] z 1866 roku, którego autorem był Andrej Červenák. Sformułował on tezę, jak powinno rozwijać się słowackie życie publiczne, polityka, gospodarka, edukacja w kontekście planowanej ugody austro-węgierskiej, ale także w związku z tak zwanym kryzysem wschodnim i ogólną sytuacją Słowian. W dokumencie tym można znaleźć wiele krytycznych punktów dotyczących polityki Rosji. Autor zaznaczył, że Rosję osłabia jej własna ekspansja, a szczególnie ta na południu Europy ${ }^{28}$. Rosja powinna zatem pozostać w obrębie swojego terytorium, w ten sposób nie szkodziłaby innym Słowianom i pomogłoby to ustabilizować sytuację w dużej części Europy. Za jeden z elementów stabilizujących, zapisany w dokumencie, uważano utworzenie niepodległego ,polsko-litewskiego" państwa połączonego z Rosją tylko przez unię personalną ${ }^{29}$.

W słowackiej polityce na początku lat 60 . XIX wieku ukształtował się drugi, bardziej liberalny, kierunek, tak zwana Nowa Szkoła. Jej przedstawiciele swoje opinie

${ }^{23}$ Svetozor, „Pešt'budinske vedomosti”, 29 V 1863, nr 43, s. 2; Svetozor, „Pešt'budinske vedomosti”, 2 X 1863, nr 79, s. 1.

24 B.K., Boj Poliakov proti Rusom, „Pešt'budínske vedomosti”, 30 VI 1863, nr 52, s. 1-2; Z Prahy, „Pešt'budínske vedomosti”, 6 XI 1863, nr 89, s. 3.

25 Svetozor, „Pešt'budínske vedomosti”, 9 VI 1863, nr 46, s. 1-2; 16 VI 1863, nr 48, s. 2.

26 R.d., V Turci, „Pešt'budínske vedomosti”, 13 III 1863, nr 21, s. 2.

27 „Cirkevní listy” 1863, s. 161, 167; Zprávy zahraničné, „Pešt'budínske vedomosti”, 19 VI 1863, nr 49, s. 4.

28 Dokumenty k slovenskému národnému hnutiu II, zost. F. Bokes, Bratislava 1965, s. 18.

29 Ibidem, s. 15. 
prezentowali głównie na łamach czeskich gazet i słowackich czasopism kulturalnych $^{30}$. Nie dowierzali oni Wiedniowi, a za głównego przeciwnika wszystkich narodów i demokratów uważali wiedeński (w tekstach określany jako „niemiecki”) centralizm. Przejawiali oni zrozumienie dla patriotyzmu węgierskiego; starali się znaleźć sposób zrozumienia węgierskiej polityki; wierzyli, że we współpracy z rządem peszteńskim będą w stanie rozwiązać także problemy słowackie. Do walki z Wiedniem reprezentanci Nowej Szkoły zaproponowali utworzenie koalicji sił węgierskich (wszystkie madziarskie, słowiańskie i rumuńskie prądy polityczne) i wezwali do ścisłej współpracy zasiadających w Radzie Państwa w Wiedniu czeskich i polskich federalistów w walce o rozszerzenie praw konstytucyjnych i federalizację monarchii. Mieli oni nadzieję, że w przypadku powodzenia tego sojuszu i osłabienia Wiednia, także Słowacy otrzymają oczekiwane prawa narodowe, włącznie z autonomią w ramach Węgier ${ }^{31}$. Właśnie z kręgu Nowej Szkoły wywodzili się Słowacy, którzy jako ochotnicy wzięli udział w powstaniu styczniowym ${ }^{32}$.

Przedstawiciele Nowej Szkoły opowiadali się także za wzajemnością słowiańską, a jednocześnie reprezentowali silnie polonofilskie stanowisko. Rosję postrzegali jako mało cywilizowane państwo, krytykowali ją przede wszystkim za politykę skierowaną przeciwko Polakom, współczuli im, rozumieli ich niefortunny los i potępiali wyrządzone im krzywdy. Ta polonofilska koncepcja została najbardziej przekonująco przedstawiona przez dramaturga Jána Palárika, zwłaszcza w artykule $O$ vzájomnost $i$ slovanskej [O wzajemności słowiańskiej] i w jego dramatach ${ }^{33}$. Określa on wzajemność słowiańską jako przejaw miłości do innych plemion słowiańskich i wsparcie ich interesów oraz aspiracji. Nie oznacza to jednak, że jakieś plemię słowiańskie powinno zrezygnować z własnej niezależności i interesów, a z miłości stać się niewolnikiem innego. Wzajemności słowiańskiej ,nic tak nie zaprzecza, jak panowanie jednego plemienia nad drugim"34. Słowianie powinni żyć jak równoprawni bracia. Palárik twierdził zupełnie inaczej niż Štúr, że celem wzajemności słowiańskiej i polityki jest „,nie jedno scentralizowane wielkie państwo słowiańskie, ale tyle niezależnych i wolnych państw słowiańskich, ile jest plemion" ${ }^{35}$.

Palárik tłumaczył nienawiść Polaków do Rosjan położeniem politycznym tych pierwszych. Uważał, że Polacy mają prawo się bronić, ponieważ Rosjanie nie chcą ich uznać za „równoprawnego, wolnego i niezależnego brata”36. Tak, według Palárika, zachowywałoby się każde słowiańskie plemię, gdyby było uciskane i poniżane przez Rosjan. Doceniał politykę cara Aleksandra I, który dał Królestwu Polskiemu konstytucję, ale po powstaniu w 1830 roku, które okazało się wielkim nieszczęściem

${ }^{30}$ Zob. V. Borodovčák, Ohlas polského povstania roku 1863 na Slovensku, Bratislava 1960, s. 90-94.

31 J. Palárik, op. cit., s. 76, 82.

32 V. Borodovčák, op. cit., s. 161, 162, 170-172.

33 W 1864 r., a więc krótko po stłumieniu polskiego powstania, Palárik napisał dramat Dymitr Samozwaniec, w którym w metaforyczny sposób przedstawił ekspansywność Rosji przeciwko Polakom.

34 J. Palárik, op. cit., s. 185.

35 Ibidem, s. 186.

36 Ibidem, s. 186. 
nie tylko dla Polaków, ale wszystkich Słowian, Polacy utracili autonomię i konstytucję, zerwana została nić słowiańskiej polityki łącząca dwa największe ,plemiona słowiańskie". Ta, zdaniem Palárika, mogłaby się odnowić tylko wtedy, kiedy w Rosji, która dla pozostałych Słowian stanowiła wzór na polu twórczości literackiej, zmieniłby się system rządów i zostałyby wprowadzone swobody polityczne i obywatelskie ${ }^{37}$.

Podobną jak Palárik koncepcję wzajemności słowiańskiej opracował także główny przedstawiciel Nowej Szkoły Ján Nepomuk Bobula i wyraził ją przede wszystkim w artykule Naši bratia Poliaci [Nasi bracia Polacy]. Odpowiedział na propozycje polskiej emigracji, aby utworzyć unię Słowian, ale bez Słowian rosyjskich. Także Bobula uzależniał funkcjonowanie wzajemności słowiańskiej od przestrzegania zasad równości, demokracji oraz samodzielności i interesów każdego narodu słowiańskiego. Również on krytykował okrucieństwa władz rosyjskich wobec Polaków. Uważał, że Słowianom bardzo pomogłoby, gdyby despotyczna Rosja przekształciła się w demokratyczne państwo. Sytuacja nierosyjskich Słowian była jednak taka, że nie daliby rady złamać absolutyzmu w Rosji, mocarstwie o wielkiej sile. Słowianie nie mogą - twierdził - wyzwać Rosji do walki tym bardziej, że mają także innych przeciwników i wrogów. Dlatego nie można ignorować Rosji. Apelował, aby Słowianie - także Polacy - zbliżyli się z rosyjskimi Słowianami, wspólnie starali się o zmianę reżimu w Rosji i zyskanie wolności dla wszystkich Słowian ${ }^{38}$. Publicyści Nowej Szkoły bronili nie tylko Polaków żyjących w zaborze rosyjskim, ale także tych, którzy znaleźli się w granicach zjednoczonych Niemiec; w tym celu często wykorzystywali antyniemieckie stereotypy i uprzedzenia ${ }^{39}$.

Na początku lat 70. XIX wieku taki kształt rozważań o charakterze polonofilskim faktycznie zniknął ze środowiska słowackiego. Niszczące konsekwencje austro-węgierskiej ugody silniej oddziaływały na życie polityczne, społeczne i kulturalne Słowacji niż na inne narody monarchii i Węgier. Bezwzględna polityka narodowa rządu węgierskiego i innych instytucji państwowych spowodowała, że bardziej liberalny kierunek polityczny Nowej Szkoły stracił zdolność manewrowania i rozpadł się. Stara Szkoła, która przekształciła się w Słowacką Partię Narodową (Slovenská národná strana), stawała się tym bardziej konserwatywna i rusofilska, o ile jej pozycja była słabsza, a sytuacja Słowaków gorsza. Zainteresowanie sprawami polskimi w następnych dziesięcioleciach ograniczało się głównie do informowania o polskich kulturalnych, zwłaszcza literackich wydarzeniach i sukcesach ewentualnie o historii Polski. Kwestia polska jako problem polityczny i państwowy zaczęła się pojawiać w słowackim dziennikarstwie dopiero na przełomie XIX i XX wieku w kontekście rozważań o zmianach sytuacji geopolitycznej, kryzysie bałkańskim, a przede wszystkim

37 Ibidem, s. 192.

38 J.N. Bobula, Naši bratia Poliaci, „Slovenské noviny”, 3 V 1871, nr 68, s. 1-2. „Slovenské noviny" opublikowały kilka artykułów, które były bliskie opiniom J.N. Bobuli i J. Palárika, zob. V. Borodovčák, op. cit., s. 124-126.

39 (B.), Poliaci a Nemci, ,Slovenské noviny”, 19 IV 1871, nr 57, s. 1. 
o stopniowym tworzeniu nowych sojuszy politycznych i militarnych w Europie. To znaczy w związku ze zmianami, jakie stawiały Słowian, a więc Polaków i Słowaków, przed nowymi możliwościami i zarazem zagrożeniami ${ }^{40}$.

\section{Przettumaczyła Bożena Kotuła}

\section{BIBLIOGRAFIA}

\section{Źródła}

\section{Źródta drukowane}

Dokumenty k slovenskému národnému hnutiu I, zost. F. Bokes, Bratislava 1962.

Dokumenty k slovenskému národnému hnutiu II, zost. F. Bokes, Bratislava 1965.

Dokumenty slovenskej národnej identity a štátnosti I, Bratislava 1998.

Frič J. V., Paměti, Praha 1960.

Listy Jána Francisciho 1, pripr. M. Eliáš, Martin 1990.

Palárik J., Za reč a práva l'udu. Kultúrnopolitické články, Bratislava 1956.

Štúr L., Slovanstvo a svet budúcnosti, Bratislava 1993.

Prasa

„Cirkevní listy” (Skalica) 1863-1864.

„Pešt'budínske vedomosti” (Budín, Turčiansky Svätý Martin) 1861-1863.

„Slovenské noviny” (Pešt') 1869-1871.

\section{Opracowania}

Bik Z., „Do Stowaków, którzy jeden dom wraz z galicjanami zamieszkują”. Dzieje tajnej misji księcia Adama Czartoryskiego na Stowacji [w:] Księga pamiatkowa ku czci Profesora Wacława Felczaka, red. A. Cetnarowicz, C.G. Kiss, I. Kovács, Kraków 1997, s. $128-136$.

Borodovčák V., Ohlas pol'ského povstania roku 1863 na Slovensku, Bratislava 1960.

Divéky A., Węrzy a Polacy w XIX stuleciu, Warszawa-Lublin-Lódź-Kraków 1918.

Haraksim L', Od Kollárova slovanství k slovenství (1835-1848) [w:] Slovanství v národním životě Čechů a Slováki̊, Praha 1968, s. 158-167.

40 Słowackie koncepcje polityki zagranicznej z okresu dualizmu były przedmiotem rozważań w wielu publikacjach: D. Kováč, Anglicko a Francúzsko v slovenskom zahraničnopolitickom myslení [w:] D. Kováč [a kol.], Sondy do slovenských dejín v dlhom 19. storoči, Bratislava 2013, s. 70-85; M. Písch, Trojspolok a Trojdohoda v slovenskej buržoáznej politike, „Historický časopis” 1975, nr 23, s. 533-542; M. Podrimavský, Slovenské pohl'ady na Európu v druhej polovici 19. storočia [w:] Zborník Filozofickej fakulty Univerzity Komenského - Historica, XLIV, Bratislava 1999, s. 111-116. 
Haraksim L., Slovanská idea v obrozenské ideologii Slováků [w:] Slovanství v národním životě Čechů a Slováků, red. V. Šṫastný et al., Praha 1968, s. 134-142.

Hurban J. M., Ludovit Štúr - Rozpomienky, Bratislava 1959.

Hvišč J., Slovensko-pol'ské literárne vzt’ahy (1815-1918), Bratislava 1991.

Kováč D., Anglicko a Francúzsko v slovenskom zahraničnopolitickom myslení [w:] Sondy do slovenských dejín v dlhom 19. storočí, a kol. D. Kováč, Bratislava 2013, s. 70-85.

Nešt'áková D., Reflexia pol'skej otázky v slovenskej preromantickej a romantickej literatúre [w:] Štúdie k jubileu Jána Kollára, ed. P. Podolan, Bratislava 2012, Historia nova 5, s. 113-143.

Písch M., Trojspolok a Trojdohoda v slovenskej buržoáznej politike, „Historický časopis” 1975, nr 23, s. 533-542.

Podrimavský M., Slovenské pohl'ady na Európu v druhej polovici 19. storočia [w:] Zborník Filozofickej fakulty Univerzity Komenského - Historica, XLIV, Bratislava 1999, s. 111-116.

Rapant D., Slovenské povstanie roku 1848-49, Diel V, čast' 2: Mená a veci, Bratislava 1972.

Škvarna D., Obraz Ruska u neslovanských a slovanských národov habsburskej monarchie [w:] Východná dilema strednej Európy, a kol.T. Ivantyšynová, D. Kodajová, Bratislava 2010, s. 19-30.

Žáček V., Z revolučných a politických pol'sko-slovenských stykov v dobe predmarcovej, Bratislava 1966. 